\title{
Gamification for Diabetes Type I Management: A Review of the Features of Free Apps in Google Play and App Stores
}

This article was published in the following Dove Press journal: Journal of Multidisciplinary Healthcare

\section{Demah Alsalman \\ Zahra M Bu Ali \\ Zainab F Alnosaier \\ Norah A Alotaibi \\ Turki M Alanzi (D)}

Health Information Management and Technology Department, College of Public Health, Imam Abdulrahman Bin Faisal University, Dammam, Saudi Arabia
Correspondence: Turki M Alanzi Health Information Management and Technology Department, College of Public Health, Imam Abdulrahman Bin Faisal University, King Faisal Road, Dammam 3|44I, Saudi Arabia

$\mathrm{Tel} / \mathrm{Fax}+966133332703$

Email talanzi@iau.edu.sa
Purpose: The objective of this study was to review most of the existing free m-Health applications (Apps) that use the gamification approach to manage diabetes type 1 in both App and Google Play stores.

Methods: Free mobile health applications "apps" that were related to diabetes mellitus have been identified in both App and Google Play stores. In order to cover all the mentioned applications, the following keywords, "game for type 1 diabetes" and "gamification for type 1 diabetes" were used in English and Arabic languages. All applications that were collected in the inclusion process were carefully analyzed, and the game name, game description, game features, game mechanics, game themes, and operating systems were recorded.

Results: A total of eight gamified applications related to type 1 diabetes were identified. Seven of these applications were in English language and only one application was in Arabic language. The applications were categorized into three main categories based on the theme of the application. The categories were taking care of a character, quizzes, and the storytelling theme. Moreover, there was no application that included the social networking feature.

Conclusion: This study highlighted the most important features of the free mobile health applications "apps" for diabetes type 1 available in Google Play and App stores that can contribute to enhance the self-management of the diabetes condition by patients in Saudi Arabia. The identified applications have important characteristics that can be used in the future for the care and self-control of type 1 diabetic patients in Saudi Arabia.

Keywords: gamification, diabetes type 1, applications, Google Play store, App store, mobile health, m-Health, mobile health applications, digital health

\section{Introduction}

Mobile health applications are considered one of the key innovation developments across a wide range of clinical areas including diabetes care and self-management. ${ }^{1}$ These m-Health "apps" can improve the quality of health care create greater awareness and knowledge about disease management, improve patient experience, health outcomes, and reduce treatment costs.

In this sense, consumers started to use pocket-sized mobile devices as an alternative to personal computers since 2007. Some of these devices are known as smartphones and the downloadable software that are "run" by them are called applications. Each week, almost 15,000 applications are being released. ${ }^{2}$ This number indicates the huge growth of mobile health applications "apps" which show no sign of slowing and 
suggest the increasing development and design of a variety of mobile health applications "apps" with different purposes. ${ }^{2}$

In recent years, the health sector has been engaged with mobile health applications "apps" as a way to improve health. According to Stevens et al, there are approximately 7000 health applications. ${ }^{3}$ These applications can serve to improve health in many different ways. ${ }^{3}$ One of the most essential ways in which applications can contribute to improving health is through self-management education. Self-management education is an approach in which the patient becomes more knowledgeable about his or her condition; therefore, the patients can take decisions regarding the treatment options which suit their personal needs. This education will assure that the patients can manage their condition on a daily basis. ${ }^{4}$

On the other hand, the m-Health applications can promote the self-management education using the gamification concept. Gamification is an approach that consists of applying the game element terms in a non-gaming context. In other words, gamification is the use of elements of games in the design of contexts that are capable of generating positive motivations for health. ${ }^{5}$ Using the gamification concept in the healthcare sector will guide the behavior of patients based on the enjoyment and engagement features of the games. ${ }^{5}$ In particular, the concept of gamification makes health apps targeting children more attractive. However, it is worth mentioning that there is still no clear evidence that gamification implemented in m-Health applications can effectively help disease management such as diabetes type 1 .

One of the health conditions that can be positively impacted by self-management education using the gamification approach is diabetes mellitus..$^{6-10}$ Diabetes mellitus is a chronic disease that affects the body's ability to use the energy taken from food. Regarding this disease, the pancreas secrets the insulin hormone which is responsible to help the body's cells to take up the glucose from the blood. However, there are two main abnormal states in which the body cannot absorb the glucose normally. They are known as type 1 and type 2 diabetes. $^{11}$

Since 1980 until 2014, the number of adults with diabetes worldwide has increased from 108 million to 422 million. $^{12}$ In Saudi Arabia around a quarter of the adult population is affected by diabetes and is expected to increase more than double by $2030 .{ }^{13}$ Also, this country is considered to have one of the highest rates of diabetes worldwide. It is ranked the seventh country worldwide and the second in the Middle East. ${ }^{14}$ The estimated population with diabetes is 7 million and the pre-diabetic is more than 3 million. In the eastern region of Saudi Arabia, the prevalence rate of type 1 diabetes is 109.5 per 100,000 inhabitants, and the incidence rate is 27.52 per 100,000 inhabitants; a similar incidence rate is observed in the western region of the country. ${ }^{15}$ This increasing rate of diabetes is due to a number of challenges that must be overcome, including lack of awareness, physical inactivity, obesity, late diagnosis, and a high cost of treatment. ${ }^{16}$

Therefore, with the intention of contributing to alleviate the burden of this disease in the people of Saudi Arabia, the objective of this study was to review most of the existing m-Health applications (Apps) that are free and use the gamification approach to manage type 1 diabetes in both App and Google Play stores.

The scope of this review will focus on the analysis of the main features of the gamified applications. In particular, the game description, features of the game, game themes, game mechanics, and the operating system (Android and iOS) will be examined. We have focused on the analysis of free applications because they could help the management of type 1 diabetes in patients who cannot afford the high costs of treating this disease in countries like Saudi Arabia and other nations of the world. Furthermore, it should be noted that we have not reviewed paid applications that have more advanced functionalities because they are not accessible to the vast majority of diabetic patients who do not have sufficient financial resources in Saudi Arabia.

\section{Methods}

Commercial mobile health applications "apps" related to gamification for the management of type 1 diabetes available on the Google Play and App stores were reviewed in January 2019.

In order to cover all the mentioned applications, the following keywords, "game for type 1 diabetes" and "gamification for type 1 diabetes" were used as research keywords in the Google Play store (Android operating system), and App Store (iOS operating system). In addition, the same equivalent research words were also used in Arabic language.

\section{Inclusion and Exclusion Criteria}

The following inclusion criterion was employed to select the applications in both stores: 1) the applications should be in English and Arabic languages, 2) the applications must be free, 3) the applications must be related to type 1 diabetes, 4) 

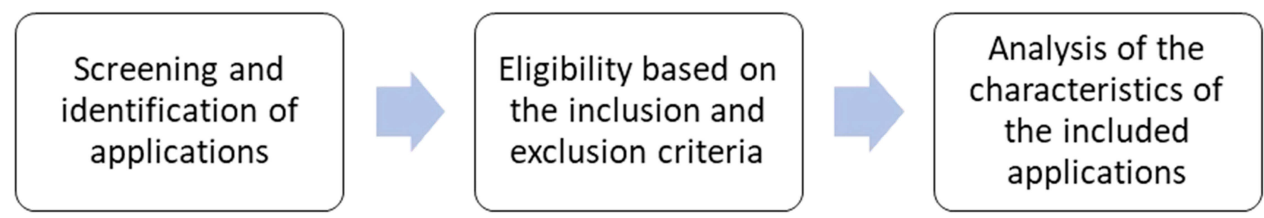

Figure I General flow diagram of the search methods.

the features of the applications must be related to gamification for type 1 diabetes. Other types of applications were excluded.

\section{Analysis of Applications}

All existing applications related to the research topics that were accessible in Google Play store and App store were screened and identified. Then, the inclusion and exclusion criteria mentioned above were applied. Finally, all applications that were collected in the inclusion process were carefully analyzed, and the game name, game description, game features, game mechanics, game themes, and operating systems were recorded. A simplified scheme of this process is shown in Figure 1.

\section{Results}

Figure 2 describes the flow diagram of the detailed search process carried out related to the identification of the commercial mobile health applications "apps" associated with gamification for the management of type 1 diabetes available on the Google Play and App stores. This figure

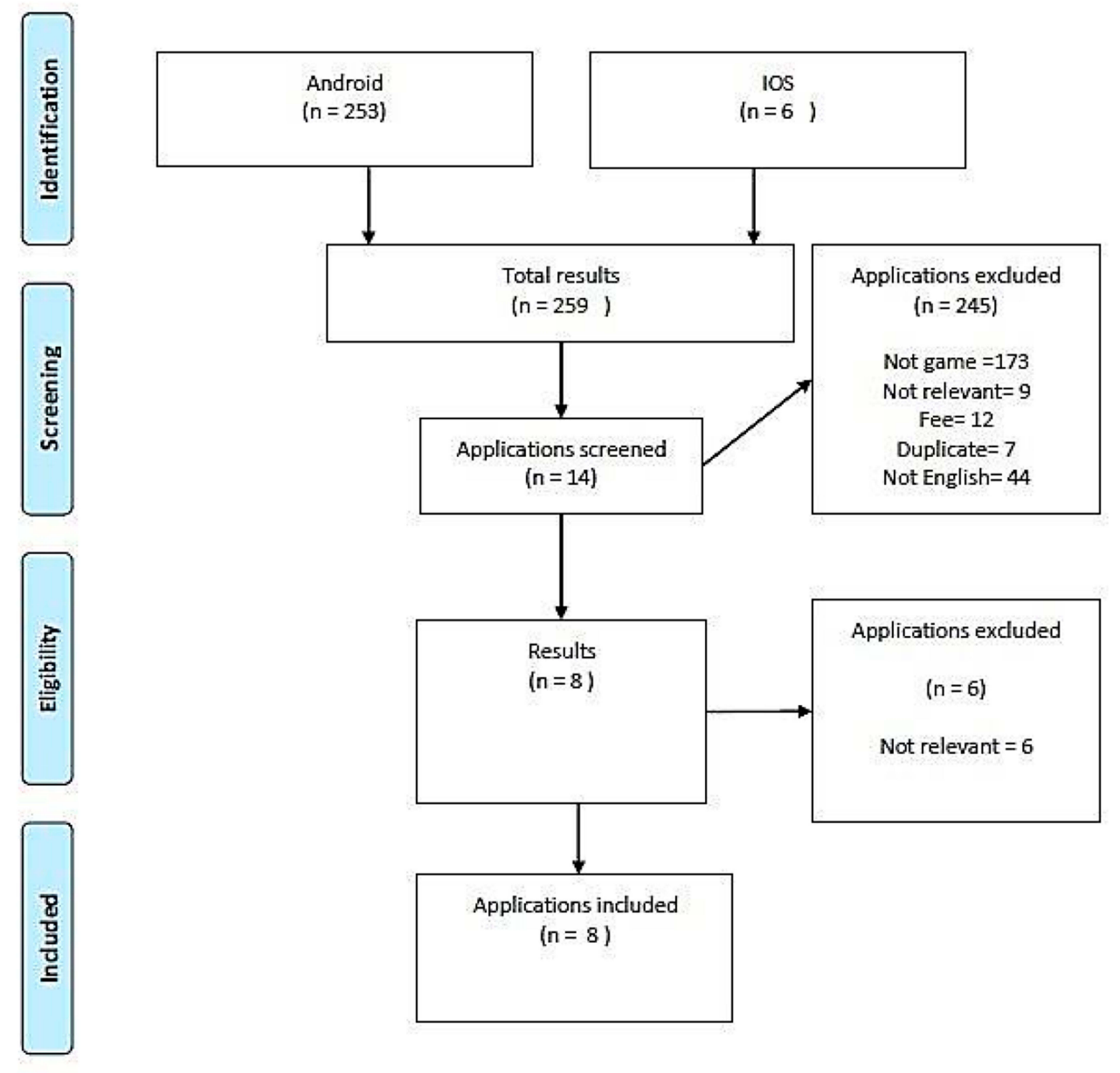

Figure 2 Detailed flow diagram of the search process. 
indicates that 259 applications were found that met the keywords used in the search. In this sense, 6 applications were detected in Google Play store (iOS operating system) and 253 in App store (Android operating system). In this figure we can observe that out of the 259 applications, only 8 applications met the inclusion criterion.

The eight gamified type 1 diabetes applications that met the inclusion criterion are described in Table $1 .^{17-24}$ This table presents the recorded data that show the main characteristics of the applications such as name of the game, description of the game, features of the game, game mechanics, game themes, and operating system. The applications were characterized according to abovementioned features.

Also, Table 2 shows the "app" features that can be best suited for Saudi diabetic patients. This information was selected from the main features shown in Table 1.

\section{Discussion}

The findings of this study associated with the commercial mobile health applications "apps" available on the Google Play and App stores linked to gamification for the management of type 1 diabetes showed that only eight gamified applications met the inclusion criterion of our research. Seven of these applications were in English language and only one application was in Arabic language.

Five of the applications used points in the game mechanics process, three of them employed levels in the game mechanics, and only one application used dashboard as a game instrument. Moreover, two games did not use any game mechanics. Furthermore, two applications have reminders and notification features for the purpose of reminding the child of checking his or her blood glucose level, medication, eating time, and doctor appointments.

In addition, five of the applications were designed using the idea of taking care of a character theme. Two of them used a bear as the character of the application. Both of these applications educate the children about the importance of eating healthy food, taking insulin injections, and checking the blood glucose level by taking care of the bear. Also, one of them used the storytelling feature. Similarly, two of the applications used a baby dragon as the character, and one of them helped to overcome the fear of insulin needles besides increasing the awareness of checking the blood glucose level on time by counting carbs of the food eaten per day. The other application focuses on the daily activities of the character such as eating, swimming, and reading the blood glucose level, and it has quiz features regarding the diabetes condition. The last application has a little boy as the character of the game, and the main idea is to educate children on the importance of taking the insulin through a space adventure where they collect the insulin points to save people of other planets. Regarding this topic, a study by McCulloch et al proved that using a character and interactive visual videos or images make the application more attractive and enhance the user-engagement with the application. $^{25}$ Additionally, engaging a character in the application contributes to adherence to medication as well as increasing the blood glucose level reading.

The quiz theme was used by two of the eight applications. One of the applications is mainly about comparing two types of food and the child should pick the food with less amount of sugar. The application includes more than 30 comparisons of more than 60 types of food. The other application includes three different types of quizzes, which are about fighting bad sugar cubes, matching healthy food to keep the blood glucose level low, and to make a comparison of more than 100 types of food with different sugar levels.

Only one of the applications depends on a storytelling theme. The main purpose of the application is to educate the children about their condition through stories, movies, and providing information regarding diabetes.

Along with taking care of a character theme, there were a number of notable features that were included in the design of these eight applications, such as reminders and notifications. Considering this issue, Cafazzo et al demonstrated that using the reminders is a reason for increasing the frequency of blood glucose level reading. ${ }^{26}$

Also, we believe that one of the most important features of the mobile applications that must be considered in the future is social interaction. According to this review, there was no application that includes a friend challenge feature. Hopefully, a study conducted by Stone proved that the use of friend's challenge enhances the self-management of diabetes condition through a competition concept. ${ }^{27}$

It is important to mention that Table 2 shows the main "app" features best suited for Saudi diabetic patients based on the information given in Table 1.

There is a notable limitation facing this review. As the number of mobile health applications "apps" is growing enormously, it is difficult to cope with the development of this industry. Therefore, by the time when this review will be published, it may not be fully updated with the existing applications. Another limitation of our work is 
Table I Description of the Applications That Met the Inclusion Criterion

\begin{tabular}{|c|c|c|c|c|c|}
\hline $\begin{array}{l}\text { Name of } \\
\text { the Game }\end{array}$ & Description of the Game & Features of the Game & $\begin{array}{l}\text { Game } \\
\text { Themes }\end{array}$ & $\begin{array}{l}\text { Game } \\
\text { Mechanics }\end{array}$ & $\begin{array}{l}\text { Operating } \\
\text { Systems }\end{array}$ \\
\hline $\begin{array}{l}\text { Jerry the } \\
\text { Bear }\end{array}$ & $\begin{array}{l}\text { It seeks to educate children about type I } \\
\text { diabetes by taking care of the } \\
\text { application's character. In addition, taking } \\
\text { care of the character will enable the } \\
\text { child to gain hands-on experience with } \\
\text { diabetes management through playing. } \\
\text { Children can check the character's blood } \\
\text { glucose level, managing insulin by } \\
\text { administrating the doses using pen or } \\
\text { pump, and feed the character with } \\
\text { a variety of food. }\end{array}$ & $\begin{array}{l}\text { - Includes storyteller } \\
\text { - Unlock story by completing a set of } \\
\text { tasks } \\
\text { - It supports family sharing feature for } \\
\text { up to six family members. (for iOS) } \\
\text { - Targeted age group }+4,6-8\end{array}$ & $\begin{array}{l}\text { Taking care } \\
\text { of } \\
\text { a character }\end{array}$ & Points & $\begin{array}{l}\text { Both } \\
\text { Android and } \\
\text { iOS }\end{array}$ \\
\hline Pandabetic & $\begin{array}{l}\text { It aims to educate type I diabetic } \\
\text { children through entertainment. The } \\
\text { children need to maintain the glucose } \\
\text { level of the character through managing } \\
\text { insulin and carbohydrates. }\end{array}$ & $\begin{array}{l}\text { - Available in three languages: (English, } \\
\text { Spanish, Italian) } \\
\text { - Social interaction through the support } \\
\text { of game center. (for iOS) } \\
\text { - It supports family sharing feature for } \\
\text { up to six family members. (for iOS) } \\
\text { - Targeted age group }+3\end{array}$ & $\begin{array}{l}\text { Taking care } \\
\text { of } \\
\text { a character }\end{array}$ & $\begin{array}{l}\text { Levels and } \\
\text { points }\end{array}$ & $\begin{array}{l}\text { Both } \\
\text { Android and } \\
\text { iOS }\end{array}$ \\
\hline Diapets & $\begin{array}{l}\text { The game encourages the diabetic child } \\
\text { to check the blood levels on time, help } \\
\text { to overcome the fear of insulin needles } \\
\text { and to count carbs. This is done through } \\
\text { taking care of a baby dragon character. }\end{array}$ & $\begin{array}{l}\text { Notification feature for reminding for } \\
\text { the eating time and for using blood } \\
\text { glucose meter. It supports family } \\
\text { sharing feature for up to six family } \\
\text { members. Targeted age group }+4,6-8\end{array}$ & $\begin{array}{l}\text { Taking care } \\
\text { of } \\
\text { a character }\end{array}$ & Points & iOS \\
\hline $\begin{array}{l}\text { Commander } \\
\text { Gage }\end{array}$ & $\begin{array}{l}\text { The game seeks to educate diabetic } \\
\text { children about the importance of taking } \\
\text { insulin for their condition. The game is } \\
\text { mainly about a character that collect } \\
\text { insulinium to save diabetic children. }\end{array}$ & $\begin{array}{l}\text { - Get the rest of the characters by col- } \\
\text { lecting more insulinium. } \\
\text { - Social interaction through the support } \\
\text { of game center. } \\
\text { - It supports family sharing feature for } \\
\text { up to six family members. } \\
\text { - Targeted age group }+4\end{array}$ & $\begin{array}{l}\text { Taking care } \\
\text { of } \\
\text { a character }\end{array}$ & Points & iOS \\
\hline $\begin{array}{l}\text { GlucoZor } \\
\text { World }\end{array}$ & $\begin{array}{l}\text { The game aims to provide education } \\
\text { about diabetes in general by taking care } \\
\text { of the game character. The user can } \\
\text { choose the color and the weight of the } \\
\text { character. The user can feed the } \\
\text { character, entertain him by many } \\
\text { activities that need to be unlocked, and } \\
\text { managing his blood glucose level. }\end{array}$ & $\begin{array}{l}\text { - Available in four languages. (English, } \\
\text { Dutch, Italian, Spanish) } \\
\text { - It includes quizzes } \\
\text { - It supports family sharing feature for } \\
\text { up to six family members. } \\
\text { - Targeted age group }+3\end{array}$ & $\begin{array}{l}\text { Taking care } \\
\text { of } \\
\text { a character }\end{array}$ & $\begin{array}{l}\text { Levels, } \\
\text { points and } \\
\text { dashboard }\end{array}$ & $\begin{array}{l}\text { Both } \\
\text { Android and } \\
\text { iOS }\end{array}$ \\
\hline $\begin{array}{l}\text { Diabetes } \\
\text { control }\end{array}$ & $\begin{array}{l}\text { The game is generally a glycemic index } \\
\text { which include certain type of food and } \\
\text { their amount of sugar. The user shall } \\
\text { choose among two type of food which } \\
\text { include less amount of sugar. }\end{array}$ & $\begin{array}{l}\text { - More than } 30 \text { comparison of more } \\
\text { than } 60 \text { types of food } \\
\text { - Great to memorize } \\
\text { - Targeted age group }+3\end{array}$ & Quizzes & $\mathrm{N} / \mathrm{A}$ & Android \\
\hline
\end{tabular}


Table I (Continued).

\begin{tabular}{|c|c|c|c|c|c|}
\hline $\begin{array}{l}\text { Name of } \\
\text { the Game }\end{array}$ & Description of the Game & Features of the Game & $\begin{array}{l}\text { Game } \\
\text { Themes }\end{array}$ & $\begin{array}{l}\text { Game } \\
\text { Mechanics }\end{array}$ & $\begin{array}{l}\text { Operating } \\
\text { Systems }\end{array}$ \\
\hline Gluco Bear & $\begin{array}{l}\text { The game aims to provide education } \\
\text { regarding the best nutrition for diabetic } \\
\text { patients. It involves a bear which get } \\
\text { through different levels by matching } \\
\text { healthy food and keeping the blood } \\
\text { glucose level low. }\end{array}$ & $\begin{array}{l}\text { - Available in three languages. (English, } \\
\text { German, Portuguese) } \\
\text { - Includes quizzes } \\
\text { - More than } 100 \text { types of food with } \\
\text { different sugar levels. } \\
\text { - Targeted age group }+3\end{array}$ & Quizzes & Levels & Android \\
\hline الطفرال & $\begin{array}{l}\text { This application supports the game } \\
\text { features. It is used for diabetic children, } \\
\text { their guardians and their teachers. It has } \\
\text { a reminder for checking blood glucose } \\
\text { level, doses time, and appointments. }\end{array}$ & $\begin{array}{l}\text { - It includes five types of games } \\
\text { - It provides information to aware chil- } \\
\text { dren regarding diabetes } \\
\text { includes stories and movies about } \\
\text { diabetes } \\
\text { - It supports family sharing feature for } \\
\text { up to six family members. (for iOS) } \\
\text { - Targeted age group }+4 \text {. }\end{array}$ & $\begin{array}{l}\text { Story } \\
\text { telling }\end{array}$ & $N / A$ & $\begin{array}{l}\text { Both } \\
\text { Android and } \\
\text { iOS }\end{array}$ \\
\hline
\end{tabular}

that there is the possibility that some applications related to gamification processes were not included in the search process because they could be classified in other game series of App and Google Play stores. Furthermore, an additional limitation of this study is related to the fact that insufficient information has been published on the assessment of the individual popularity of these "apps", the frequency of repetition or initial use, and most importantly, the link with the behavior change; in other words, it is not possible to determine whether these "apps" are purely entertainment or actually improve health behavior. So far, there is limited information about the use or acceptability of these apps for the self-management of type 1 diabetes. Also, in this study, we have not analyzed the current legal or quality framework that apps have to fulfill before being released or how this affects the marketing or labeling of apps as purely entertainment or health app, or who are the developers of the free apps, or how do such free apps generate revenue or funding for development and maintenance. In addition, we did not investigate if the social networking feature was present in paid apps or what is the legal or quality framework that gamification apps have before being released. Besides, we did not analyze how this affects the marketing of apps or who are the developers of free gamified apps for patients of diabetes type 1, and how they are

Table 2 "App" Features Best Suited for Saudi Diabetic Patients

\begin{tabular}{|c|c|}
\hline I & The m-Health "apps" should be able to send notifications to alleviate type I diabetic patients. \\
\hline 2 & $\begin{array}{l}\text { The "app" must have some features that can show how, why and where the insulin injections are used. For example, locations (abdomen } \\
\text { the applications must indicate where are the anatomy and thigh) for administrating an insulin injection. }\end{array}$ \\
\hline 3 & It is important to include an education feature to clarify and explain how children and their parents should collaborate in his process. \\
\hline 4 & $\begin{array}{l}\text { Also, it is necessary to incorporate a health education feature tailored for Ramadan religious conceptions. For instance, a story that can } \\
\text { promote the awareness of the diabetic children such as how the child can take care of himself during fasting hours. }\end{array}$ \\
\hline 5 & $\begin{array}{l}\text { Alike, a notification feature that encourage children for commitment of the five prayers since it's considered as a physical activity as well } \\
\text { as religious in Saudi Arabia }\end{array}$ \\
\hline 6 & It is necessary to use "Mulita" language for social interaction \\
\hline 7 & $\begin{array}{l}\text { The application must also contain a message about social interaction and family support that are fundamental elements in this process of } \\
\text { knowledge, improvement and recovery from this disease. }\end{array}$ \\
\hline
\end{tabular}


funded. Finally, an important limitation of this study is that there were not enough references in the literature to support all the claims of this study.

\section{Conclusion}

In this study, we have observed that there were few free mobile health applications "apps" related to the management of gamification of type 1 diabetes in Google Play and App stores. In particular, only eight applications matched the search inclusion criteria. This number is really small with respect to the approximately 7000 mobile applications that are now widely used in the health sector for various purposes such as the management of chronic diseases like diabetes. The different themes that were used in the reviewed applications were caring for a character, questionnaires, and telling stories. The outcomes obtained in this study have a practical value and can help people with type 1 diabetes in Saudi Arabia and other countries around the world. Our findings will allow using a set of free applications that can help them to alleviate this disease that requires expensive treatments.

\section{Disclosure}

The authors report no conflicts of interest in this work.

\section{References}

1. Lohnari T, Patil S, Patil S. Use of mobile applications in healthcare: a review. Int J Eng Res Gen Sci. 2016;4(1):38-42.

2. Rakestraw T, Eunni R, Kasuganti R The mobile apps industry: a case study. J Business Cases Appl. 2019. Available from: https://pdfs.seman ticscholar.org/b4fd/972d8f34de5d8c5eeec805b94642b1610223.pdf.

3. Stevens D, Jackson J, Howes N, Morgan J. Obesity surgery smartphone apps: a review. Obes Surg. 2013;24(1):32-36. doi:10.1007/ s11695-013-1010-3

4. Clement S. Diabetes self-management education. Diabetes Care 1995;18(8):1204-1214. doi:10.2337/diacare.18.8.1204

5. Sardi L, Idri A, Fernández-Alemán J. A systematic review of gamification in e-Health. J Biomed Inform. 2017;71:31-48. doi:10.1016/j. jbi.2017.05.011

6. Theng Y, Lee P, Patinadan P, Foo SSB. The use of videogames, gamification, and virtual environments in the self-management of diabetes: a systematic review of evidence. Games Health J. 2015;4 (5):352-361. doi:10.1089/g4h.2014.0114

7. Baranowski T, Baranowski J, Chen T, et al. Videogames that encourage healthy behavior did not alter fasting insulin or other diabetes risks in children: randomized clinical trial. Games Health J. 2019;8 (4):257-264. doi:10.1089/g4h.2018.0097

8. Lazem S, Webster M, Holmes W, Wolf M. Games and diabetes: a review investigating theoretical frameworks, evaluation methodologies, and opportunities for design grounded in learning theories. J Diabetes Sci Technol. 2015;10(2):447-452. doi:10.1177/19322 96815604634

9. Boulos M, Shauna G, MacRury S, et al. Digital games for type 1 and type 2 diabetes: underpinning theory with three illustrative examples. JMIR Serious Games. 2015;3(1):e3. doi:10.2196/games.3930
10. Priesterroth L, Grammes J, Holtz K, Reinwarth A, Kubiak T. Gamification and behavior change techniques in diabetes self-management apps. J Diabetes Sci Technol. 2019;13(5):954-958. doi: $10.1177 / 1932296818822998$

11. Alanzi T. Role of social media in diabetes management in the Middle East region: systematic review. J Med Internet Res. 2018;20(2):e58. doi:10.2196/jmir.9190

12. World Health Organization. WHO | diabetes mellitus; 2018. Available from: https://www.who.int/mediacentre/factsheets/fs138/ en/. Accessed December 12, 2018.

13. Robert A, Al Dawish M. The worrying trend of diabetes mellitus in Saudi Arabia: an urgent call to action. Curr Diabetes Rev. 2019;16 (3):204-10.

14. Al Dawish M, Braham R, Robert A, Ayman A. Diabetes mellitus in Saudi Arabia: a review of the recent literature. Curr Diabetes Rev. 2015;12(4):359-68.

15. Al-Herbish A, El-Mouzan M, Al-Salloum A, et al. Prevalence of type 1 diabetes mellitus in Saudi Arabian children and adolescents. Saudi Med J. 2008;29(9):1285-1288.

16. Robert A, Al Dawish M, Braham R, et al. Type 2 diabetes mellitus in Saudi Arabia: major challenges and possible solutions. Curr Diabetes Rev. 2016;13(1):59-64. doi:10.2174/1573399812666160126142605

17. Google Play. 2018. Available from: https://play.google.com/store/ apps/details?id=com.m1play.pandabetic. Accessed November 26, 2018.

18. Google Play. 2019. Available from: https://play.google.com/store/ apps/details?id=com.games.GlucoBear\&hl=en_US. Accessed January 30, 2019.

19. Google Play. 2019. Available from: https://play.google.com/store/ apps/details?id=air.com.dinnosante.glucozor\&hl=en_US. Accessed January 30, 2019.

20. Google Play. 2019. Available from: https://play.google.com/store/apps/ details?id=com.RMB.control diabetes. Accessed January 30, 2019.

21. Google Play. 2019. Available from: https://play.google.com/store/ apps/details?id=org.newver.diabities.diabities $2 \&$ hl=en_US. Accessed February 3, 2019.

22. Jerry the Bear. Jerry the Bear; 2018. Available from: https://www. jerrythebear.com/. Accessed November 26, 2018.

23. AppAdvice. 2019. Commander Gage by Fletcher/Rosen Interactive LLC. Available from: https://appadvice.com/app/commander-gage /1126606055. Accessed January 30, 2019.

24. AppAdvice. 2019. Diapets by Giancarlo Cavalcante. Available from: https://appadvice.com/app/diapets/1052313496. Accessed January 30,2019

25. McCulloch V, Hope S, Loranger B, Rea PM. Children and mobile applications: how to effectively design and create a concept mobile application to aid in the management of type 1 diabetes in adolescents. InINTED2016: 10th annual International Technology, Education and Development Conference, Valencia, Spain, 7th 2016 Mar 9.

26. Cafazzo J, Casselman M, Hamming N, Katzman DK, Palmert MR Design of an mHealth app for the self-management of adolescent type 1 diabetes: a pilot study. J Med Internet Res. 2012;14(3):e70. doi:10.2196/jmir.2058

27. Stone E 2013. Dia-BEAT-it: an online game for children and teenagers with type 1 diabetes. Available from: https://scholars.unh.edu/cgi/view content.cgi? article $=1156 \& \mathrm{amp}=\&$ context=honors $\&$ amp $=\&$ sei-redir $=1 \&$ referer $=$ https $\% 253 \mathrm{~A} \% 252 \mathrm{~F} \% 252 \mathrm{Fwww}$.bing.com $\% 252 \mathrm{Fsearch}$ $\% 253 \mathrm{Fq} \% 253 \mathrm{Ddia}-$ beatit $\% 25253 \mathrm{~A} \% 252 \mathrm{Ban} \% 252 \mathrm{Bonline} \%$ 252 Bgame $\% 252$ Bfor $\% 252$ Bchildren $\% 252$ Band $\% 252$ Bteenagers $\%$ 252 Bwith $\% 252$ Btype \% 252 B 1\%252 Bdiabetes \% 2526 go\% 253DSearch $\% 2526 q$ s $\% 253$ Dds $\% 2526$ form $\% 253$ DQBRE\#search $=\%$ 22dia-beat-it $\% 3$ A $\% 20$ an $\% 20$ online $\% 20$ game $\% 20$ children $\% 20$ teen agers\%20type\%201\%20diabetes\%22. Accessed March 20, 2019. 


\section{Publish your work in this journal}

The Journal of Multidisciplinary Healthcare is an international, peerreviewed open-access journal that aims to represent and publish research in healthcare areas delivered by practitioners of different disciplines. This includes studies and reviews conducted by multidisciplinary teams as well as research which evaluates the results or conduct of such teams or healthcare processes in general. The journal covers a very wide range of areas and welcomes submissions from practitioners at all levels, from all over the world. The manuscript management system is completely online and includes a very quick and fair peer-review system. Visit http://www.dovepress.com/testimonials. php to read real quotes from published authors.

Submit your manuscript here: https://www.dovepress.com/journal-of-inflammation-research-journal 